\title{
Hydrogen ICE Vehicle Testing Activities
}

\section{SAE 2006 World Congress}

\author{
James Francfort \\ Don Karner
}

April 2006

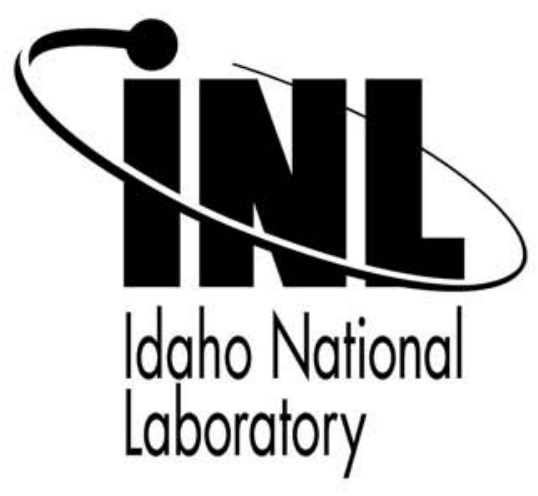

This is a preprint of a paper intended for publication in a journal or proceedings. Since changes may not be made before publication, this preprint should not be cited or reproduced without permission of the author. This document was prepared as an account of work sponsored by an agency of the United States Government. Neither the United States Government nor any agency thereof, or any of their employees, makes any warranty, expressed or implied, or assumes any legal liability or responsibility for any third party's use, or the results of such use, of any information, apparatus, product or process disclosed in this report, or represents that its use by such third party would not infringe privately owned rights. The views expressed in this paper are not necessarily those of the United States Government or the sponsoring agency. 


\title{
Hydrogen ICE Vehicle Testing Activities
}

\author{
James Francfort \\ Idaho National Laboratory \\ Don Karner \\ Electric Transportation Applications
}

\begin{abstract}
The Advanced Vehicle Testing Activity teamed with Electric Transportation Applications and Arizona Public Service to develop and monitor the operations of the APS Alternative Fuel (Hydrogen) Pilot Plant. The Pilot Plant provides $100 \%$ hydrogen, and hydrogen and compressed natural gas (H/CNG)-blended fuels for the evaluation of hydrogen and H/CNG internal combustion engine (ICE) vehicles in controlled and fleet testing environments. Since June 2002, twenty hydrogen and $\mathrm{H} / \mathrm{CNG}$ vehicles have accumulated 300,000 test miles and 5,700 fueling events. The AVTA is part of the Department of Energy's FreedomCAR and Vehicle Technologies Program. These testing activities are managed by the Idaho National Laboratory. This paper discusses the Pilot Plant design and monitoring, and hydrogen ICE vehicle testing methods and results.
\end{abstract}

\section{INTRODUCTION}

The U.S. Department of Energy's Advanced Vehicle Testing Activity (AVTA) teamed with Electric Transportation Applications (ETA) and Arizona Public Service (APS) to develop the APS Alternative Fuel (Hydrogen) Pilot Plant (Figure 1). The Pilot Plant produces up to 18 kilograms $(\mathrm{kg})$ of hydrogen per day via electrolysis. Hydrogen is compressed to 6,000 pounds per square inch (psi), and up to 155 kilograms of hydrogen are stored at various pressures (up to $6,000 \mathrm{psi}$ ).

The hydrogen is produced by separating water into hydrogen and oxygen by operating a proton exchange membrane (PEM) fuel cell in reverse. The Pilot Plant ${ }^{1}$ also compresses natural gas (CNG) on site, obtaining the natural gas from street service. Fuel dispensers and a credit card billing system are used to fuel internal combustion engine (ICE) vehicles that operate on $100 \%$ hydrogen, $100 \%$ CNG, and blends of 15,30 and $50 \%$ hydrogen and CNG (H/CNG).

The AVTA supports the development of industry and DOE technology targets by providing benchmark data for technology modeling, and research and development programs, by testing and validating the performance of vehicles that feature advanced technologies. The testing results are also leveraged as input to component, system, and vehicle models, as well as hardware-in-theloop testing.

The AVTA is part of DOE's FreedomCAR and Vehicle Technologies Program. These testing activities are conducted by the Idaho National Laboratory and its testing partner, Electric Transportation Applications, Phoenix, Arizona. Contractual management is provided by DOE's National Energy Technology Laboratory.

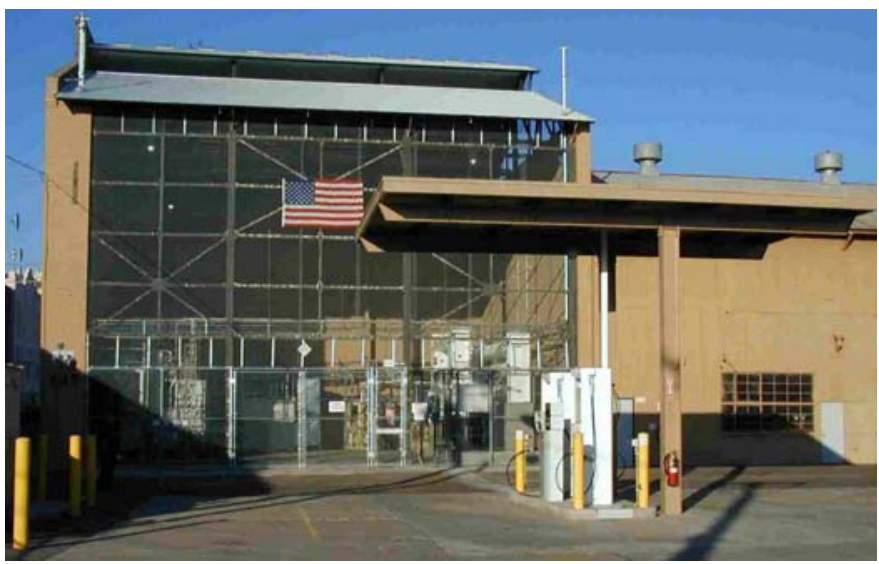

Figure 1. APS Alternative Fuel (Hydrogen) Pilot Plant.

\section{APS ALTERNATIVE FUEL (HYDROGEN) PILOT PLANT}

The objectives for constructing and operating the Pilot Plant are to:

- Ascertain the safety issues of hydrogen production in a commercial setting

- Evaluate the adequacy of existing codes, standards, regulations, and recommended practices in a commercial setting

- Establish models for future codes and standards for distributed hydrogen generation systems within a commercial setting 
- Determine performance limitations of existing technologies and components

- Evaluate hydrogen and blended $\mathrm{H} / \mathrm{CNG}$ as a potential fuel for ICE vehicles

- Develop a working model of a refueling system for hydrogen vehicles.

The Pilot Plant, which has been operating continuously since June 2002, is sited in downtown Phoenix, Arizona to determine the full impact of existing codes and standards, and building inspection requirements on station design and on the siting process. This approach is unique to hydrogen fueling station design in the United States; it provides insight into the requirements for hydrogen fueling stations to be constructed and operated in commercial, rather than industrial, areas.

\section{PILOT PLANT - HYDROGEN SUBSYSTEM}

The Pilot Plant's hydrogen subsystem (Figure 2) has six primary functions: production, drying, low-pressure storage (Figure 3), compression, filtering, and highpressure storage. The subsystem produces hydrogen in the PEM fuel cell (57 kW, 300 scfh output) at 150 psi. The PEM output is then dried and stored $(9,000 \mathrm{scf})$ at 150 psi. As needed, the hydrogen is next compressed, filtered, and stored $(17,000 \mathrm{scf})$ at $6,000 \mathrm{psi}$, where it is ready for use at $99.9997 \%$ purity.

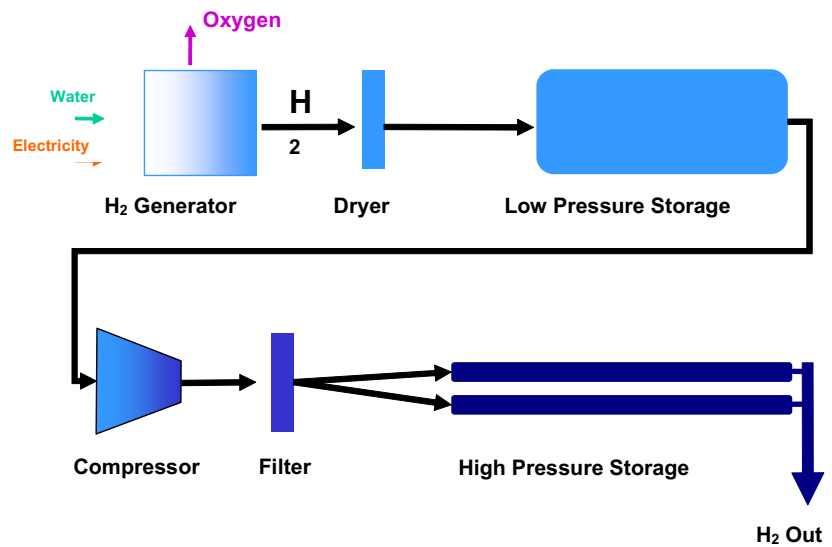

Figure 2. The APS Alternative Fuel (Hydrogen) Pilot Plant hydrogen subsystem.

The capacities of the carbon steel storage vessels, rate of hydrogen production, and rate of compression are all coordinated to achieve the required refueling demand. The hydrogen system offers an opportunity to evaluate system reliability, cost, and safety, and is a source of fuel for both fuel cell vehicles (provided as a courtesy to vehicle manufacturers testing their fuel cell vehicles at Phoenix-area test tracks) and ICE vehicles the AVTA is testing.

The EMS (emergency shutdown system) enables complete system shutdown, automatically or manually initiated. EMS alarm and annunciation visually and audibly indicate that the EMS has been initiated.

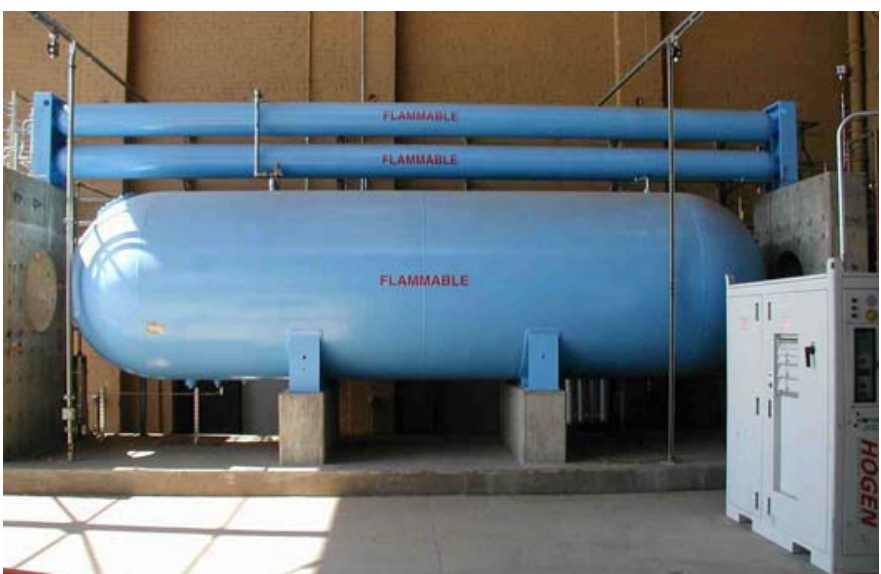

Figure 3. Low-pressure hydrogen storage tank (large, lower tank), high-pressure storage tanks (two upper tanks), and HOGEN fuel cell (right).

The hydrogen system is a completely sealed, closed system. Proper piping design ensures that hydrogen is not inadvertently released. However, should a hydrogen leak occur, hydrogen gas detectors (Det-Tronics RS 8471 units) (Figure 4 ) will signal an alarm at $25 \%$ of the lower flammability limit (LFL) of hydrogen and isolate the hydrogen system at $50 \%$ of LFL, with automatic shutdown of power to the operating equipment (the control power, monitoring, and communication systems remain energized).

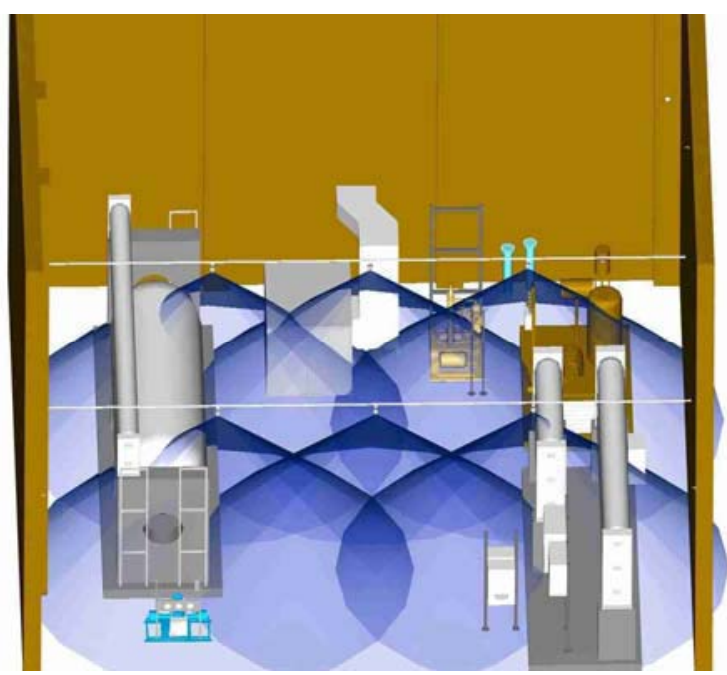

Figure 4. Coverage area of the six combustible hydrogen gas detectors from Det-Tronics.

Six flame detectors (Spectrex 20/20LB units) continuously scan the gas building for both infrared (IR) and ultraviolet (UV) wavelength or flame signature (Figures 5 and 6). If the flame detectors are alarmed, the hydrogen system is automatically shutdown by isolating all hydrogen storage, production, and dispensing, and by shutting off the power supply to the PEM generator, dryer, and compressor. There is also a seventh IR/UV flame detector unit at the dispenser island. 


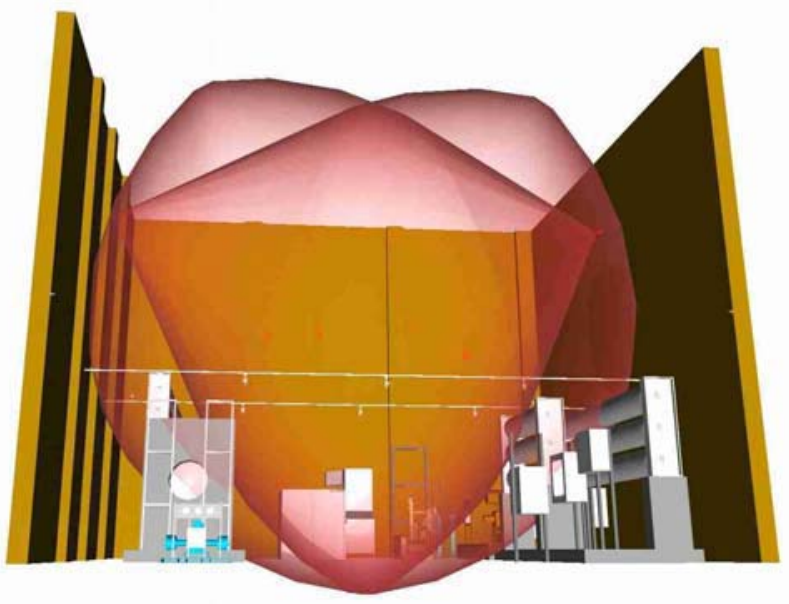

Figure 5. Four IR and UV corner flame detectors.

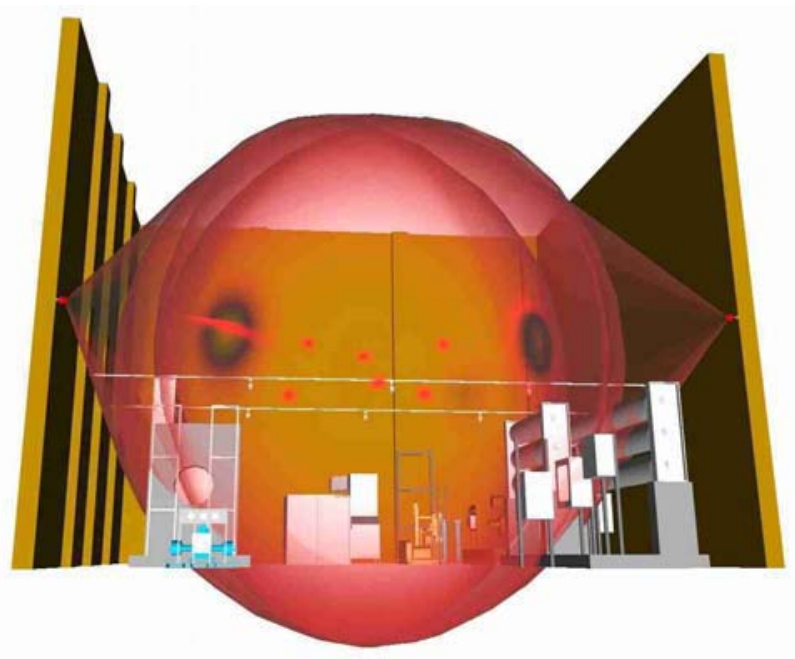

Figure 6. Two IR and UV midlevel flame detectors.

Any venting or draining of the system is to the vent stack, where hydrogen is released above the roofline of the building. Design of the system eliminates any direct human contact with hydrogen. A helium purge is available to inert the vent stack, and a nitrogen purge is used as an intermediary in any event that requires opening of the hydrogen system. Nitrogen purge points have been strategically designed into the system to adequately ensure safe operation and maintenance. In addition, all of the equipment has been well grounded to eliminate static electricity and lightning as an ignition source.

\section{PILOT PLANT—CNG SUBSYSTEM}

The objectives of constructing and operating the CNG subsystem are to:

- Evaluate the cost and benefit of operating a natural gas fueling system

- Evaluate the safety of a natural gas fueling system

- Provide a fuel source for AVTA- and APS-operated CNG and H/CNG ICE vehicles.

The CNG subsystem (Figure 7) includes compression of natural gas from street service by way of a boost compressor (60 psi) and a main compressor (5,000 psi). Using six storage tanks, the CNG is stored using a three-stage cascade pressure arrangement at 3,600 (3 tanks), 4,500 (2 tanks), and 5,000 psi (1 tank), which allows cascade CNG fueling operations and the blending of CNG with hydrogen (Figure 8).

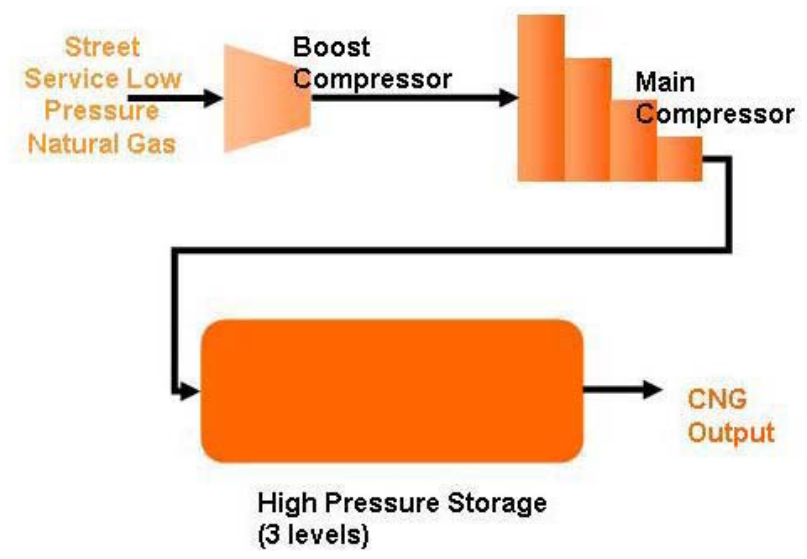

Figure 7. APS Alternative Fuel Pilot Plant compressed natural gas subsystem.

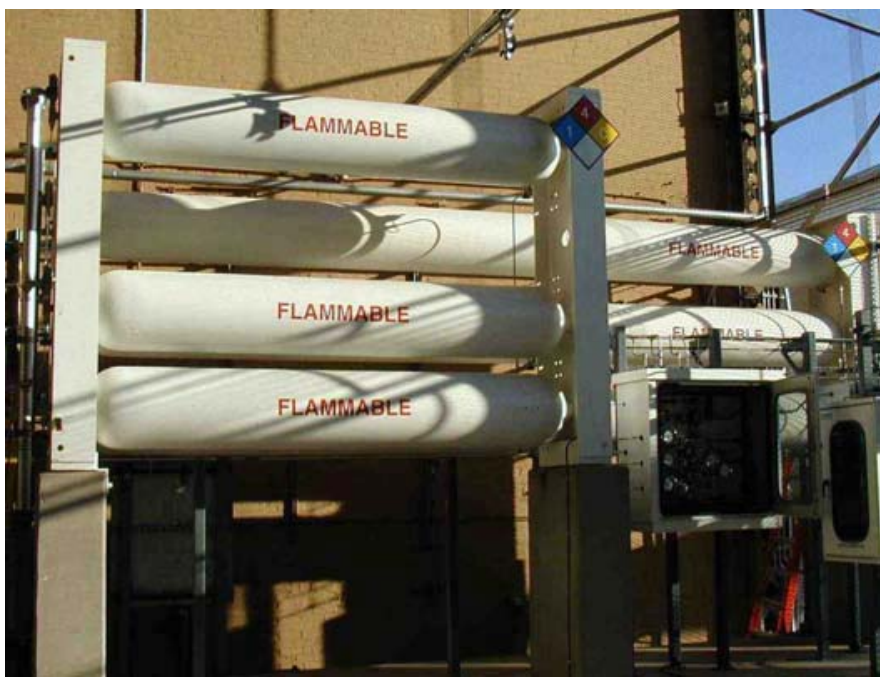

Figure 8. Compressed natural gas (CNG) tanks.

\section{PILOT PLANT—FUEL DISPENSING}

The hydrogen and CNG motor fuel is dispensed by independent dispensers. One dispenser is used for $100 \%$ hydrogen and $\mathrm{H} / \mathrm{CNG}$ blends, and one dispenser is used for CNG (Figure 9). The hydrogen dispenser is dual-station: one hose dispenses $100 \%$ hydrogen into a vehicle with a pressure rating up to $5,000 \mathrm{psi}$; the other hose dispenses $\mathrm{H} / \mathrm{CNG}$ blends at a pressure rating of up to $3,600 \mathrm{psi}$. The CNG dispenser has two identical hoses, providing CNG at a pressure rating of up to 3,600 psi.

Each dispenser has its own display. The displays indicate the amount of fuel dispensed in GGE (gasoline gallon equivalents), the unit cost per GGE, and the total cost for the fuel dispensed. The output hose assemblies and the nozzle that connects to the vehicle are coordinated with the type of fuel to be dispensed. 
Thereby, the nozzle from the hydrogen dispenser can be connected only to a vehicle designed for hydrogen, and the nozzle from the CNG dispenser can be connected only to a vehicle designed for CNG. Both dispensers interact with the electronic billing interface.

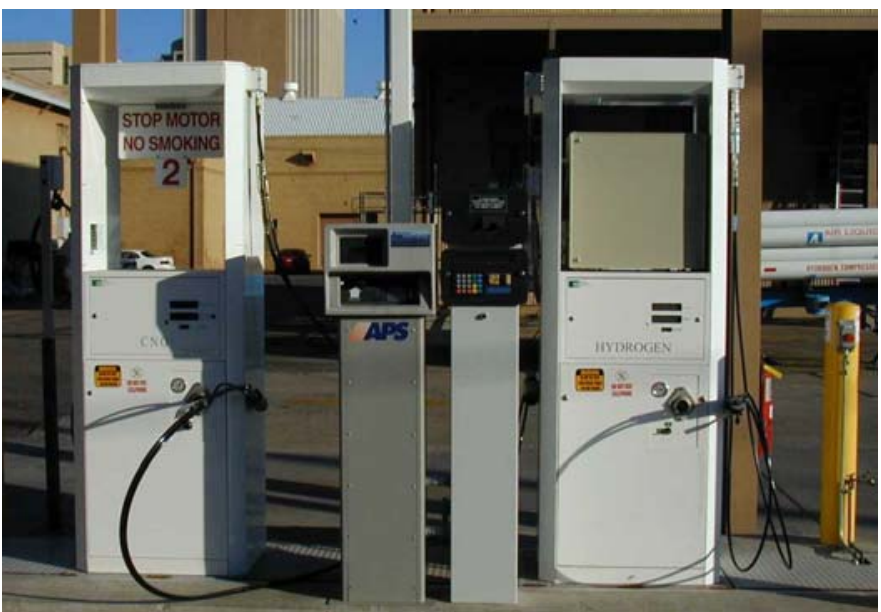

Figure 9. Compressed natural gas dispenser (left) and hydrogen and $\mathrm{H} / \mathrm{CNG}$ fuels dispenser (right), with the two credit card interface pedestals in between.

The AVTA is currently testing a prototype gaseous fuel dispenser $^{2}$ (Figure 10). The dispenser delivers three types of fuels: $100 \%$ hydrogen, $100 \%$ CNG, and H/CNG blends via two independent single nozzles. The $100 \%$ hydrogen nozzle is rated at 5,000 psig. The second nozzle is rated at 3,600 psig and is used for both CNG and H/CNG fuels. This nozzle connects to both CNG and hydrogen supply lines, and blends the fuels to supply $\mathrm{H} / \mathrm{CNG}$ levels of $15,20,30$, and $50 \%$ (by volume).

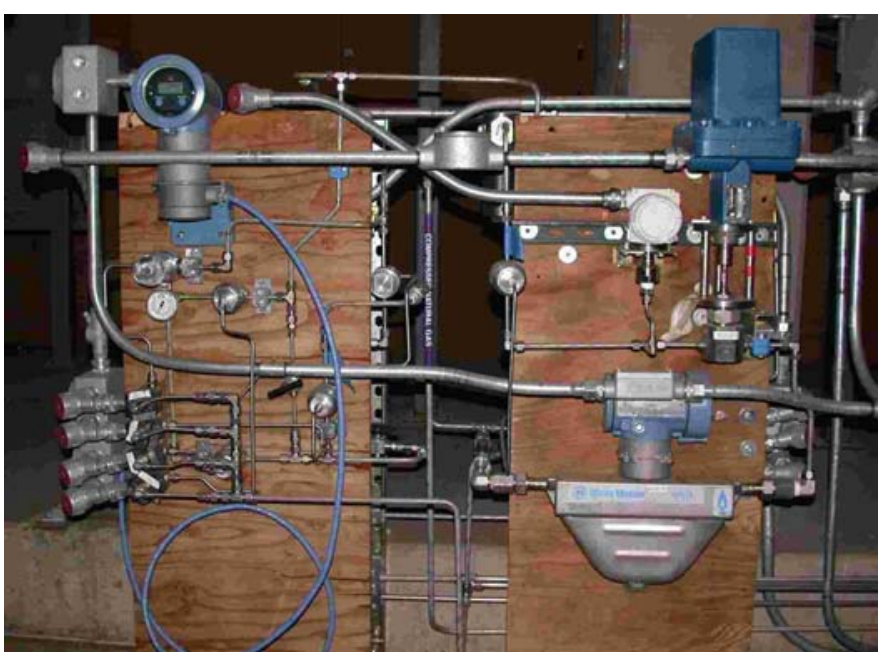

Figure 10. Prototype gaseous fuel dispenser brassboard design.

The prototype dispenser incorporates proportional flow control valves for both hydrogen and CNG gas streams in order to control gas flow rates from 100 to 40,000 scfh. These flow rates support fast fueling times (less than five minutes for typical light- and medium-duty vehicles). The control valves are trimmed by a digital dispenser controller using mass flow signals provided by coriolis mass flow transducers in both gas streams. The dispenser controller adjusts the control valves to provide real-time ratio control of blended fuels.

\section{PILOT PLANT-MONITORING ACTIVITIES AND RESULTS}

The Pilot Plant is being monitored to determine the costs to produce hydrogen fuels $(100 \%$ hydrogen and $\mathrm{H} / \mathrm{CNG}$ blends).

The monitoring system ${ }^{3}$ was designed to track hydrogen delivery to each of the three storage areas (a tube trailer is sometimes used for additional hydrogen storage) and to monitor the use of electricity on all major equipment in the Pilot Plant, including the fuel dispenser island. In addition, water used for the electrolysis process is monitored to allow calculation of the total cost of plant operations and plant efficiencies. The monitoring system at the Pilot Plant will include about 100 sensors when complete (50 are installed to date), allowing for analysis of component, subsystem, and plant-level costs.

The monitoring software is mostly off-the-shelf, with a custom interface. The majority of the sensors input to the Programmable Automation Controller as 4- to 20-mA analog signals. The plant can be monitored over of the Internet, but the control functions are restricted to the control room equipment.

Using the APS general service plan E32 electric rate of 2.105 cents per kWh, during a recent eight-month period when $1,200 \mathrm{~kg}$ of hydrogen were produced at a plant capacity factor of $26 \%$, the electricity cost to produce one $\mathrm{kg}$ of hydrogen was $\$ 3.43$. However, the plant capacity factor has been increasing, with a recent onemonth high of $49 \%$. If a plant capacity factor of $70 \%$ can be achieved with the present equipment, the electricity cost would drop to $\$ 2.39$ per $\mathrm{kg}$ of hydrogen. The power conversion $(76.7 \%)$, cell stack $(53.1 \%)$, and reverse osmosis system $(7.14 \%)$ efficiencies, and the water cost per $\mathrm{kg}$ of hydrogen produced ( $\$ 0.10$ per $\mathrm{kg}$ ) have all been calculated.

Since the inception of operations, the Pilot Plant has produced a total of 7,200 kilograms of hydrogen. While the majority of the Pilot Plant's 5,700 fueling events have been for CNG, there have been 300 fueling events for $100 \%$ hydrogen and 1,200 H/CNG fueling events. In addition, there have been zero lost time accidents associated with plant operations.

\section{HYDROGEN AND H/CNG ICE VEHICLE TESTING}

The AVTA is evaluating hydrogen and H/CNG ICE vehicles in closed-track and laboratory environments (baseline performance testing), as well as in real-world fleet testing applications. Emissions testing has also been conducted on several vehicles. Testing and operating hydrogen and H/CNG ICE vehicles also support development of the hydrogen infrastructure needed for fuel-cell vehicles. 
The ICE test vehicles that operate on $100 \%$ hydrogen and 15 to $50 \% \mathrm{H} / \mathrm{CNG}$ blends include Daimler Chrysler, Dodge, Ford, and General Motors vehicles. The vehicles that operate on $15 \% \mathrm{H} / \mathrm{CNG}$ are unmodified CNG vehicles from original equipment manufacturers (OEM). The vehicles that operate on greater than $15 \% \mathrm{H} / \mathrm{CNG}$ blends or $100 \%$ hydrogen have been modified to varying degrees by non-OEM entities. The modifications usually include superchargers and custom fuel rail systems. In addition, hydrogen storage tanks are used onboard the $100 \%$ hydrogen ICE vehicles. The hydrogen and H/CNG ICE vehicles tested or currently in testing include:

- $100 \%$ hydrogen Mercedes Benz van ${ }^{4}$

- Ford F-150 operating on up to $30 \% \mathrm{H} / \mathrm{CNG}^{5}$

- Ford F-150 operating on up to $50 \% \mathrm{H} / \mathrm{CNG}^{6}$

- Dodge van operating on $15 \% \mathrm{H} / \mathrm{CNG}^{7}$

- Eight APS meter reader vehicles (S-10 and Sierra pickups, and Blazers) operating on 15\% H/CNG

- Ford F-150 operating on $100 \%$ hydrogen, with a 5.4 liter, 16-valve engine

- Ford F-150 operating on $100 \%$ hydrogen, with a 5.4 liter, 32-valve engine.

The above test vehicles have accumulated a total of 300,000 test miles since June 2002.

\section{MERCEDES SPRINTER VAN ON 100\% HYDROGEN}

The primary objective for operating this vehicle was to provide hands on experience with the use of hydrogen, to determine the safety issues associated with dispensing hydrogen into motor vehicles, and to evaluate the safety and reliability of operating vehicles on hydrogen. The Sprinter van (Figure 11) was operated on $100 \%$ hydrogen for 4,300 miles.

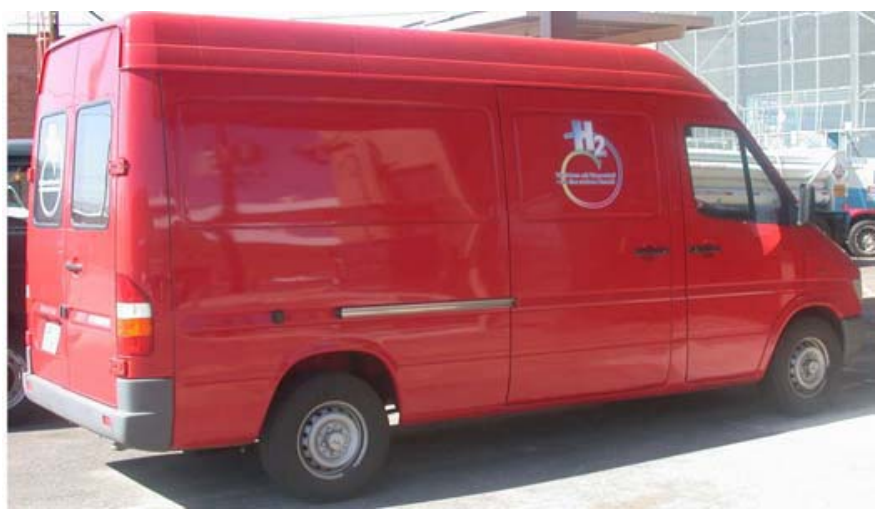

Figure 11. 100\% hydrogen Mercedes Sprinter van.

The 1998 Mercedes Sprinter was originally equipped with a 2.4-liter gasoline internal combustion engine. The German government in Hamburg, Germany converted the engine to operate using pure hydrogen. The modifications included adding three 3,600 psi steel hydrogen tanks (115 liters), constant volume mechanical fuel injection, and spark ignition modifications. When the vehicle was received, a WEH 5,000 psi inlet was installed to make the vehicle compatible with the Pilot
Plant. The fuel storage tanks installed on the Sprinter operate at 3,600 psi. Inasmuch as this vehicle operates using $100 \%$ hydrogen, its only potential emission is nitrogen oxide. No testing for nitrogen oxide was performed on the Sprinter.

Drivers of the Sprinter van reported rough operation: "It sounds like a diesel engine." Drivers also reported a dead spot in the accelerator. The only operational problem occurred when the vehicle failed to start after refueling. It was determined that a failure to fully shut the fuel door caused the fueling interlock switch not to release. This was, therefore, an operator error. No safety problems were observed during the Sprinter's operation.

Limited fuel-use data indicated that the Mercedes Sprinter operated at 20 miles per GGE. Based on German experience with this vehicle, this would appear to be an unrealistically high fuel economy. It is believed that the short period over which fuel use measurement was available significantly reduced the reliability of the fuel economy measurement.

This vehicle is still operated in the APS fleet.

\section{FORD F-150 ON UP TO 30\% H/CNG BLENDED FUELS}

Various fuel blends (100\% CNG, 15\% H/CNG, and $30 \%$ $\mathrm{H} / \mathrm{CNG}$ fuels) were tested in this vehicle to allow comparison of performance and emissions impacts. The up-to-30\% H/CNG vehicle started as a CNG bifuel Ford F-150 and the modifications included adding an Eaton mechanical supercharger with an air-to-water intercooler with approximately 3 psi of boost, and the OEM engine controls were replaced with Motec engine and spark controllers. In addition, adjustable exhaust gas recirculation levels were incorporated. The vehicle utilizes the factory-installed steel carbon 3,600 psi CNG fuel tank.

Comparing the $30 \% \mathrm{H} / \mathrm{CNG}$ and $100 \%$ CNG emissions results showed the nonmethane hydrocarbons $(-44 \%)$, carbon monoxide $(-25 \%)$, and carbon dioxide $(-5 \%)$ emissions all decreased with the use of $30 \% \mathrm{H} / \mathrm{CNG}$ fuel, while the methane $(8 \%)$ and oxides of nitrogen (15\%) levels increased (Table 1). When compared to gasoline fuel emissions, the up-to-30\% H/CNG F-150 exhibited significantly lower emissions (Table 2).

Table 1. Emissions results in grams per mile for blended $\mathrm{H} / \mathrm{CNG}$ and $100 \%$ CNG operations.

\begin{tabular}{|c|c|c|c|c|c|c|c|}
\hline \multirow{2}{*}{$\begin{array}{c}\text { Fuel } \\
\text { Blend }\end{array}$} & \multirow{2}{*}{$\begin{array}{l}\text { Vehicle } \\
\text { Mileage }\end{array}$} & \multicolumn{6}{|c|}{ Emission Species (gram/mile) } \\
\hline & & $\mathrm{NMHC}$ & $\mathrm{CH}_{4}$ & $\mathrm{HC}$ & $\mathrm{CO}$ & $\mathrm{NO}_{\mathrm{X}}$ & $\mathrm{CO}_{2}$ \\
\hline $\mathrm{CNG}$ & 30,045 & 0.023 & 0.128 & 0.173 & 0.567 & 0.110 & 473.1 \\
\hline $\begin{array}{c}15 \% \\
\mathrm{H} / \mathrm{CNG}\end{array}$ & 29,915 & 0.025 & 0.132 & 0.179 & 0.467 & 0.124 & 452.2 \\
\hline $\begin{array}{c}30 \% \\
\mathrm{H} / \mathrm{CNG}\end{array}$ & 28,814 & 0.013 & 0.138 & 0.175 & 0.423 & 0.126 & 448.1 \\
\hline $\begin{array}{l}\mathrm{CO}=\mathrm{carl} \\
\mathrm{NO}_{\mathrm{x}}=\mathrm{oxi} \\
\mathrm{CO}_{2}=\mathrm{car}\end{array}$ & $\begin{array}{l}\text { n monox } \\
\text { es of nitro } \\
\text { on dioxide }\end{array}$ & $n$ & $\begin{array}{l}\mathrm{VMHC}= \\
\mathrm{CH}_{4}=\mathrm{m} \\
\mathrm{HC}=\mathrm{tot}\end{array}$ & $\begin{array}{l}\text { onme } \\
\text { lane } \\
\text { hydro }\end{array}$ & arbons & carb & \\
\hline
\end{tabular}


The F-150 was also performance tested, and the acceleration rates and ranges decreased with the use of higher hydrogen levels (Table 3 ). However, this vehicle reached a top speed of over $100 \mathrm{mph}$ within 50 seconds with all three fuel types (Figure 12).

Table 2. Percentage reduction in emissions $(30 \%$ $\mathrm{H} / \mathrm{CNG}$ fuel versus gasoline-fueled $\mathrm{F}-150$ ).

\begin{tabular}{cccc}
\hline $\mathrm{HC}$ & $\mathrm{CO}$ & $\mathrm{NO}_{\mathrm{x}}$ & $\mathrm{CO}_{2}$ \\
\hline $7.6 \%$ & $83.5 \%$ & $53.4 \%$ & $29.4 \%$ \\
\hline $\mathrm{HC}=$ total hydrocarbons & $\mathrm{CO}=$ carbon monoxide \\
$\mathrm{NO}_{\mathrm{x}}=$ oxides of nitrogen & $\mathrm{CO}_{2}=$ carbon dioxide &
\end{tabular}

Table 3. F-150 test vehicle acceleration to $60 \mathrm{mph}$ and fuel economy and range testing results at a constant speed of $45 \mathrm{mph}$ for $100 \% \mathrm{CNG}, 15$ and $30 \% \mathrm{H} / \mathrm{CNG}$.

\begin{tabular}{lccc}
\hline Fuel Blend & $\begin{array}{c}\text { Time to } 60 \\
\mathrm{mph}\end{array}$ & Economy (miles/gge) & Range (miles) \\
\hline $100 \% \mathrm{CNG}$ & 10.10 & 23.3 & 122 \\
$15 \% \mathrm{H} / \mathrm{CNG}$ & 10.97 & 22.6 & 110 \\
$30 \% \mathrm{H} / \mathrm{CNG}$ & 12.68 & 23.5 & 102 \\
\hline
\end{tabular}

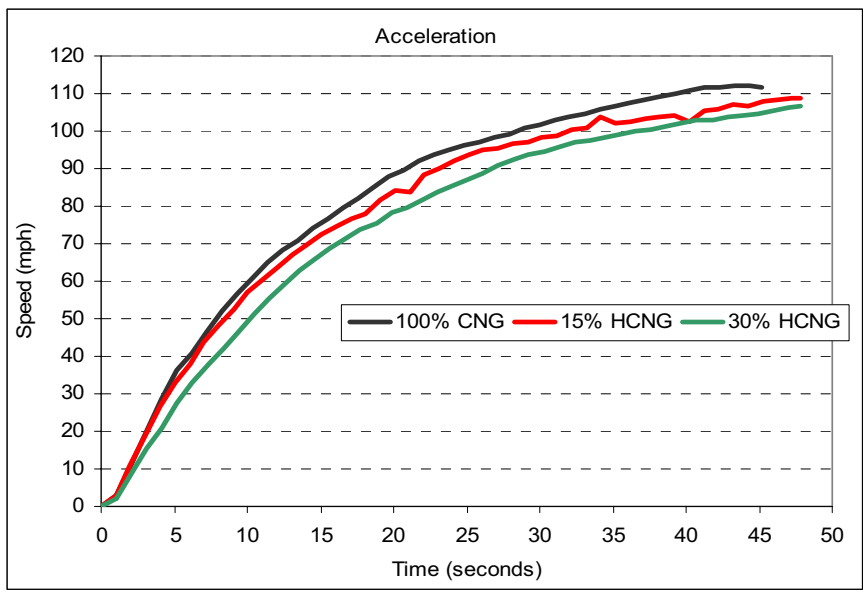

Figure 12. Acceleration times for the CNG bifuel F-150 tested with $100 \% \mathrm{CNG}, 15 \% \mathrm{H} / \mathrm{CNG}$, and $30 \% \mathrm{H} / \mathrm{CNG}$ fuels.

This vehicle continues to be actively driven.

\section{DODGE VAN ON 15\% H/CNG BLENDED FUEL}

The Dodge van operating on $15 \% \quad H / C N G$ has accumulated the most test miles on a single vehicle, with 71,000 miles as of September 2005. No modifications were made to the 5.2 liter V8 engine in this vehicle. The OEM 3,600-psi fuel tanks were used.

By blending CNG with $15 \%$ hydrogen, emission levels were generally reduced, as shown in Table 4 . Nitrogen oxide (NOx) emissions, however, increased substantially. Review of the original test data reveals that the rise in NOx levels from the H/CNG-fueled van occurred in phases 1 and 3 of the FTP-75 test (cold start and hot start phases, respectively).

Emissions during each phase of the FTP-75 test are shown in Table 5. Phase 1 NOx emissions increased by
$70 \%$, and phase 3 NOx emissions increased by $142 \%$. During phase 2, the transient phase, NOx emissions were actually reduced by $40 \%$ for the HCNG-fueled van compared to the $100 \%$ CNG-fueled van. The rise in NOx levels with the addition of hydrogen to the fuel can be attributed to the fact that the vehicle had no engine modifications and was not optimized to burn H/CNG.

This vehicle continues to be actively driven.

Table 4. Percentage change in $\mathrm{H} / \mathrm{CNG}$ emissions compared to CNG operations emissions.

\begin{tabular}{ll}
\hline Total hydrocarbons & $-34.7 \%$ \\
Carbon monoxide & $-55.4 \%$ \\
Oxides of nitrogen & $+92.1 \%$ \\
Carbon dioxide & $-11.3 \%$ \\
\hline
\end{tabular}

Table 5. FTP-75 NOx emissions by phase in grams per mile.

\begin{tabular}{ccllllll}
\hline FTP-75 & & CNG & & & H/CNG & & Percent \\
Phase & Test 1 & Test 2 & Avg. & Test 1 & Test 2 & Avg. & Change \\
1 & .254 & .337 & .296 & .482 & .527 & .505 & +70 \\
2 & .008 & .002 & .005 & .004 & .002 & .003 & -40 \\
3 & .096 & .136 & .116 & .268 & .294 & .281 & +142 \\
\hline
\end{tabular}

FORD F-150 ON UP TO 50\% H/CNG BLENDED FUELS

The up-to-50\% H/CNG F-150 was a model year 2001 Ford F-150 equipped with a factory gasoline engine (260 HP, 5.4 liter V8). It was originally modified to run on a blend of $30 \% \mathrm{H} / \mathrm{CNG}$. The modifications included replacing the stock cylinder heads with heads from the Ford SVO program utilizing larger valves, adding an Easton mechanical supercharger with an air-to-water intercooler (5 psi boost), incorporating adjustable exhaust gas recirculation with an exhaust gas cooler for water removal, replacing the OEM engine controls with Motec fuel and spark controls, and adding three hydrogen fuel tanks from Quantum Technologies. The tanks had an inner polymer liner, a carbon fiber reinforced shell, and a tough external shell that enhanced damage protection. The tanks had a maximum actual working pressure of 4,400 psi and a service pressure of 3,600 psi.

The vehicle was originally operated on $30 \% \mathrm{H} / \mathrm{CNG}$ for 5 months, and then the engine was retuned to operate on $50 \% \mathrm{H} / \mathrm{CNG}$. The primary goal of testing this vehicle on $\mathrm{H} / \mathrm{CNG}$ blends was to evaluate the safety and reliability of operating such a system. No safety problems were encountered with fueling or operating the F-150 using either 30 or $50 \% \mathrm{H} / \mathrm{CNG}$ fuels. The vehicle also demonstrated consistent, reliable behavior; it had no operating problems. The vehicle achieved very low emissions compared to gasoline engines and had near zero NOx levels (Table 6). Compared to a gasolinefueled F-150, when operating on the $30 \% \mathrm{H} / \mathrm{CNG}$ fuel, this vehicle exhibited notable decreases in emissions (Table 7).

This vehicle is no longer being operated. 
Table 6. Up-to-50\% H/CNG Ford emissions testing (FTP-75) results at 87 miles while operating on $30 \%$ $\mathrm{H} / \mathrm{CNG}$. Results in grams per mile.

\begin{tabular}{lccccc}
\hline $\mathrm{NMHC}$ & $\mathrm{CH}_{4}$ & $\mathrm{HC}$ & $\mathrm{CO}$ & $\mathrm{NOx}$ & $\mathrm{CO}_{2}$ \\
0.0014 & 0.108 & 0.123 & 0.879 & 0.005 & 518.1 \\
\hline \multicolumn{2}{c}{$\mathrm{CO}=$ carbon monoxide } & \multicolumn{2}{l}{$\mathrm{NMHC}=$ nonmethane Hydrocarbons } \\
$\mathrm{NO}_{\mathrm{x}}=$ oxides of nitrogen & \multicolumn{2}{l}{$\mathrm{CH}_{4}=$ methane } \\
$\mathrm{CO}_{2}=$ carbon dioxide & \multicolumn{2}{l}{$\mathrm{HC}=$ total hydrocarbons }
\end{tabular}

Table 7. Percentage decrease in emissions $(30 \%$ $\mathrm{H} / \mathrm{CNG}$ versus gasoline-fueled $\mathrm{F}-150$ )

\begin{tabular}{cccc}
\hline $\mathrm{HC}$ & $\mathrm{CO}$ & $\mathrm{NOx}$ & $\mathrm{CO}_{2}$ \\
$-3.5 \%$ & $-43.3 \%$ & $-97.0 \%$ & $-16.7 \%$ \\
\hline $\mathrm{CO}=$ carbon monoxide & $\mathrm{NOx}=$ oxides of nitrogen & \\
$\mathrm{CO}_{2}=$ carbon dioxide & $\mathrm{HC}=$ total hydrocarbons &
\end{tabular}

\section{BACKGROUND - 100\% HYDROGEN ICE PICKUPS}

The $100 \%$ hydrogen 16 - and 32-valve ICE Ford pickups (discussed next) are development prototypes, designed to identify the problems and possibilities of hydrogen ICE vehicles. Pickups were chosen as hydrogen tanks can easily be installed in their beds. The 16-valve pickup was designed as the low-cost option, in order to understand how economically a $100 \%$ hydrogen ICE vehicle could be built. The 32-valve pickup was designed to maximize performance and energy efficiency (40+\% efficient on the engine dynamometer), with only some regard to economic constraints. The prototype development and testing goal was to determine the economic and performance parameters for hydrogen ICE vehicles. The GMC Sierra pickup is the result of this development process. There has not been any OEM involvement in this process.

Primary consideration was given to successfully mapping the engines (fuel and ignition), as just making the engines work successfully is a significant success. As for emissions, the objective was to produce less oxides of nitrogen that the equivalent gasoline-equipped vehicle. Various technologies exist that can be used to control oxides of nitrogen, and when complete, the GMC Sierra will produce lower NOx than the gasoline base vehicle. Both the 32-valve F-150 and the GMC Sierra will be rigorously measured in a calibrated laboratory during the first quarter of 2006 and reported on during the oral presentation at the SAE World Congress.

While vehicle-specific information is provided in each of the following three sections, several comments are applicable to all pickups:

- It may be possible to extend oil change intervals in hydrogen ICEs. Preliminary oil sampling suggests a lower rate of contaminate accumulation in the engine oils. However, this has not been a research priority to date.

- The hydrogen injectors use the OEM injection ports.

- External oil vapor separators are used to ensure no oil is introduced into the air intakes via the crankcase ventilation systems.
FORD F-150 (16-VALVE) ON 100\% HYDROGEN FUEL

The 16-valve, $100 \%$ hydrogen ICE Ford F-150 pickup (Figure 13) completed AVTA baseline performance testing during the spring of 2005. A 5.4 liter two-valveper-cylinder Ford modular V8 engine was installed in this vehicle. The engine modifications included incorporating a mechanical supercharger and air-to-water intercooler (3 psi boost), replacing the stock valves and seats with hardened valves and valve seats, replacing the stock pistons with forged units raising the compression ration to $12: 1$, replacing the stock engine controls with Motec fuel and spark controls, replacing the stock fuel injectors and fuel rail with hydrogen-specific units. The engine was tuned to operate in a lean-burn mode with lambda values of 2.4 to 2.6. Onboard hydrogen is stored in three Dynetek tanks at 3,000 psi. The 3,000 psi tanks were used as they were available from a previous project. The tanks consist of aluminum inner vessels, with a fiberglass wrap, and hold a total of 6.5 kilograms of hydrogen.

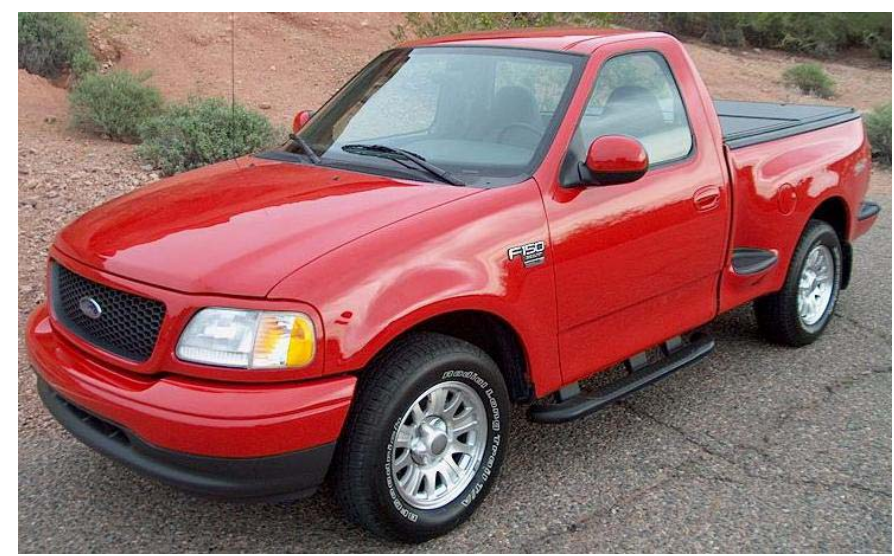

Figure 13. The 16-Valve, 5.4 liter Ford F-150 ICE vehicle that operates on $100 \%$ hydrogen.

The baseline performance testing included fuel economy testing at a constant speed of $45 \mathrm{mph}$ (Table 8), and SAE J1634 drive cycle tests, with and without the air conditioning on. Other tests included acceleration (18.1 seconds zero to $50 \mathrm{mph}$ ), maximum speed ( $81 \mathrm{mph}$ in 1 mile), braking, handling, and gradeability. The 16-valve pickup has accumulated 3,500 fleet test miles to date. During fleet testing, the vehicle has been operated at temperatures ranging from 25 to $100+{ }^{\circ} \mathrm{F}$, and elevations ranging from 1,000 to 7,000 feet above sea level.

Based on the test results, shown in Table 8, and the onboard energy storage of $6.52 \mathrm{GGE}$, the vehicle has a range of between 95 miles (14.5 miles per GGE) and 176 miles ( 27 miles per GGE). If this vehicle were to be equipped with the 5,000 psi tanks (15 total kilograms) used in the 32-valve vehicle (discussed below), it would have a range of 218 to 405 miles per fill-up.

This vehicle was previously emissions tested, but the engine was retuned after the testing was complete, so reporting these emissions results would be misleading. 
This vehicle continues in active fleet testing.

Table 8. Baseline performance testing results for a 2003 F-150, 5.4 liter internal combustion truck, operating on $100 \%$ hydrogen.

\begin{tabular}{|l|c|c|c|}
\hline Test & $\begin{array}{c}\text { Fuel Economy } \\
\text { (miles/GGE) }\end{array}$ & $\begin{array}{c}\text { Fuel Used } \\
\text { (GGE) }\end{array}$ & $\begin{array}{c}\text { Range } \\
\text { (miles) }\end{array}$ \\
\hline $\begin{array}{l}\text { SAE J1634 Drive Cycle } \\
\text { With Air }\end{array}$ & 14.5 & 4.897 & 94.5 \\
\hline $\begin{array}{l}\text { SAE J1634 Drive Cycle } \\
\text { Without Air }\end{array}$ & 18.0 & 3.956 & 117.4 \\
\hline Constant Speed at 45 mpg & 27.0 & 2.288 & 176.0 \\
\hline Fleet Testing & 17.2 & 162.791 & 112.1 \\
\hline
\end{tabular}

Fuel economy is in miles per gasoline gallon equivalent (GGE). Range based on onboard hydrogen fuel capacity of 6.52 GGE. The baseline performance testing included SAE J1634 Drive Cycle testing performed with and without air conditioning and at a constant speed of $45 \mathrm{mph}$. The fleet testing results are after 2,880 miles.

\section{FORD F-150 (32-VALVE) ON 100\% HYDROGEN FUEL}

The 32-valve $100 \%$ hydrogen ICE Ford F-150 (Figure 14) will complete AVTA baseline performance testing in early 2006. A 5.4 liter four-valve-per-cylinder Ford module V8 was installed in this vehicle. The engine modifications included incorporating an Autorotor mechanical supercharger and air-to-air intercooler (12 psi boost), replacing the stock piston with forged units raising the compression ration to $11.5: 1$, replacing the stock engine controls with Motec fuel and spark controls, and replacing the stock fuel injectors and fuel rail with hydrogen-specific units. The engine was tuned to operate in a lean-burn mode with lambda values of 2.6 to 3.0. Onboard hydrogen is stored in three Dynetek tanks (Figure 15), each consisting of an aluminum inner vessel and a carbon wrap. The three 5,000 psi tanks hold a total of 15 kilograms of hydrogen.

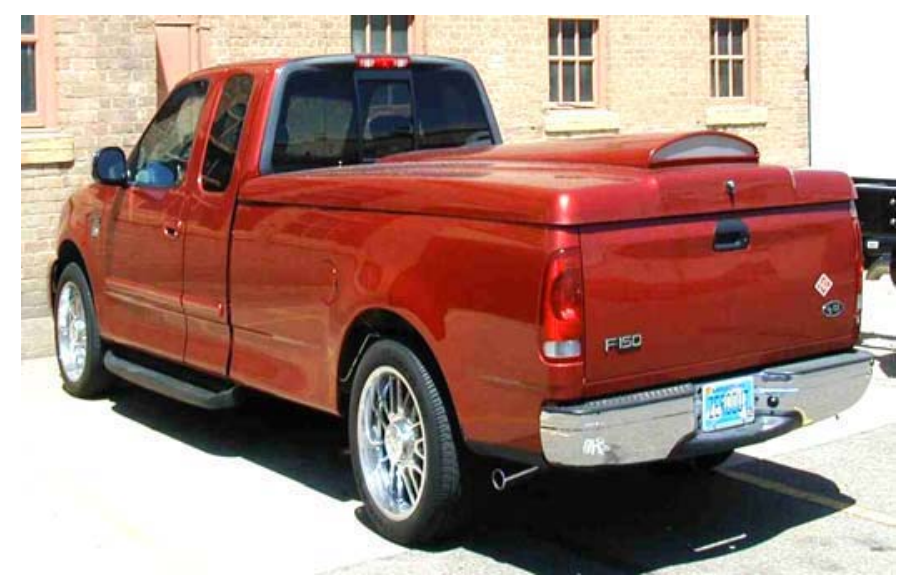

Figure 14. 32-Valve, 5.4 liter Ford F-150 converted to operate on $100 \%$ hydrogen by ETEC.

The 32-valve vehicle has accumulated a total of 7,200 miles on $100 \%$ hydrogen prior to baseline performance testing. The results of the baseline performance testing and emissions testing will be reported during the oral presentation at the 2006 SAE World Congress. It is anticipated that his vehicle will have significantly improved performance compared to the 16 -valve vehicle as it makes about $50 \%$ more horsepower.

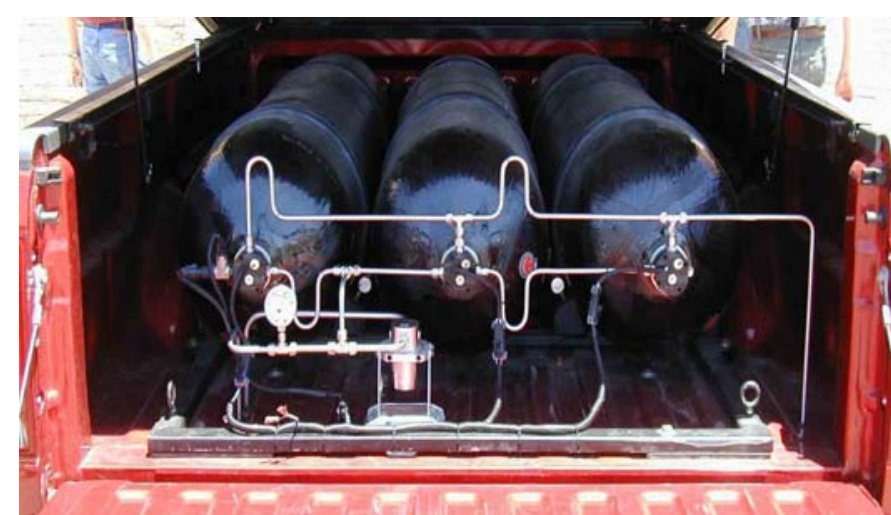

Figure 15. Dynetek aluminum inner vessel with carbon wrap hydrogen tanks.

\section{GMC SIERRA ON 100\% HYDROGEN FUEL}

A partnership consisting of Roush Industries, Powertech Labs, and Electric Transportation Engineering Corporation (ETEC) is modifying eight General Motors (GM) 1500 Sierra crew cab (4 door) pickups to operate on $100 \%$ hydrogen. The base engine is a 6 liter, V8 GM CNG ICE. This vehicle will have 10.75 kilograms of onboard hydrogen storage at 5,000 psi. The supercharged engine is anticipated to produce 180 horsepower, getting 15 miles per GGE, producing oxides of nitrogen (NOx) emissions at the same level as the stock vehicle, with zero carbon monoxide and hydrocarbon emissions. The AVTA anticipates baseline performance testing this vehicle in early 2006 and monitoring the fleet use of the eight vehicles. The baseline performance testing results will be published as part of the oral presentation.

\section{CONCLUSIONS}

- The Pilot Plant has safely produced $7,200 \mathrm{~kg}$ of hydrogen for use as a transportation fuel since June 2002. There have been 5,700 vehicle fueling events (includes $100 \%$ hydrogen, H/CNG blends, and 100\% CNG fuels) without a lost time accident in a downtown commercial area.

- The Pilot Plant monitoring system has documented the current electricity cost of $\$ 3.43$ to produce one $\mathrm{kg}$ of hydrogen, and if a plant factor of $70 \%$ can be achieved with the present equipment, the cost of electricity would drop to $\$ 2.39$ per $\mathrm{kg}$ of hydrogen. The power conversion $(76.7 \%)$, cell stack $(53.1 \%)$, reverse osmosis system (7.14\%) efficiencies, and the water cost per $\mathrm{kg}$ of hydrogen produced $(\$ 0.10$ per $\mathrm{kg}$ ) have also been calculated.

- The Pilot Plant monitoring system has identified several areas having the potential to lower costs, including using a reverse osmosis system with higher efficiency, improving the electrolysis power conversion efficiency, and using air cooling to replace some or all chilled water cooling. 
- Several ICE vehicles operating on $100 \%$ hydrogen and $H / C N G$ blended fuels have demonstrated the safety of operating ICE vehicles on hydrogen.

- Hydrogen- and H/CNG-fueled vehicle emissions are significantly lower than similar gasoline ICE vehicles.

- When comparing the use of $100 \%$ CNG and $30 \%$ H/CNG fuels in the up-to- $30 \%$ H/CNG F-150, increased use of hydrogen decreases acceleration times (zero to $60 \mathrm{mph}$ ) and range by about $20 \%$.

- The 16-valve 5.4 liter Ford has completed baseline performance testing, and during the SAE J1634 dynamometer testing, its $100 \%$ hydrogen fuel economy was 18.0 miles per GGE with the air conditioning off and 14.5 miles per GGE with the air conditioning on. This vehicle is averaging 17 miles per GGE on $100 \%$ hydrogen in fleet testing.

- Two new $100 \%$ hydrogen ICE vehicles (Ford 32valve F150 and GM Sierra pickups) will be baseline performance tested during the next six months.

\section{REFERENCES}

1. Karner, D. and J.E. Francfort. December 2003. Arizona Public Service - Alternative Fuel (Hydrogen) Pilot Plant Design Report. INEEL-0300976. Idaho National Engineering and Environmental Laboratory. Idaho Falls, ID.

2. Karner, D., S. McCamman, and J.E. Francfort. February 2005. Hydrogen, CNG, and HCNG Dispenser System - Prototype Report. INL-0500006. Idaho National Laboratory. Idaho Falls, ID.

3. Hochard, D., and J.E. Francfort. July 2005. APS Alternative Fuel (Hydrogen) Pilot Plant Monitoring System. INL/EXT-05-00502. Idaho National Laboratory. Idaho Falls, ID.

4. Karner, D. and J.E. Francfort. January 2003. Hydrogen-Fueled Mercedes Sprinter Van Operating Summary. INEEL-03-00009. Idaho National Engineering and Environmental Laboratory. Idaho Falls, ID.

5. Karner, D. and J.E. Francfort. January 2003. LowPercentage Hydrogen/CNG Blend Ford F-150 Operating Summary. INEEL-03-00008. Idaho National Engineering and Environmental Laboratory. Idaho Falls, ID.

6. Karner, D. and J.E. Francfort. January 2003. HighPercentage Hydrogen/CNG Blend Ford F-150 Operating Summary. INEEL-03-00007. Idaho National Engineering and Environmental Laboratory. Idaho Falls, ID.

7. Karner, D. and J.E. Francfort. January 2003. Dodge Ram Wagon Van - Hydrogen/CNG Operations Summary. INEEL-03/00006. Idaho
National Engineering and Environmental Laboratory. Idaho Falls, ID.

\section{CONTACT}

James Francfort

James.francfort@inl.gov

http://avt.inl.gov

INL/CON-05-00414 